\title{
Application of slaker grits industrial waste as a primary calcium oxide source in a ceramic frit formulation
}

\author{
V.R.dos Santos ${ }^{1}$, M.D.Cabrelon ${ }^{2}, E . S$. Trichês $^{1}, E$. Quinteiro $^{1 *}$ \\ ${ }^{1}$ Universidade Federal de São Paulo, Science and Technology Institute, 12231-280, São José dos Campos, SP, Brazil \\ ${ }^{2}$ Innovare Inteligência em Cerâmica, São Carlos, SP, Brazil
}

\begin{abstract}
Wastes management studies concerning slaker grits, a rich calcium carbonate landfilled residue from the pulp and paper industry, are focused on their application in the construction field due to their calcareous nature. To the best of our knowledge, slaker grits addition in a high calcium content ceramic frit formulation and their behavior as a glaze has not yet been explored, being the aim of this work. Grits were added as a calcium oxide source in $0,50 \%$, and $100 \%$, and the frits were analyzed regarding their chemical composition, devitrification, sintering behavior, morphology, colorimetric coordinates, and scratch resistance. By means of comparison, the commercial frit was also characterized. The glazes were analyzed by their physical and thermal properties and scratch resistance. Grits did not prevent the vitreous phases obtention and, compared to the commercial frit, presented a similar behavior, although resulted in higher wollastonite devitrification that directly affected glazes' thermal properties, sintering contraction, linear thermal expansion coefficient, among others. A great outcome was the quartz scratch resistance of the glaze containing the highest grits content, revealing an optimized behavior. Grits residue proved to be a promising alternative raw material capable of generating sustainable and economic perspectives for the ceramic coating sector.
\end{abstract}

Keywords: glass, glazes, slaker grits waste, solid residues, waste management.

\section{INTRODUCTION}

The chemical recovery step of the Kraft process on pulp and paper mills generates a great amount of wastes estimated at over one million metric tons per year [1]. Generally landfilled, application of these wastes in other industrial sectors may prevent this unsustainable management, reflecting on environmental and economic advantages $[2,3]$. Among them, slaker grits are originated from the liquor causticizing step and have a chemical and mineralogical composition similar to common raw materials used in diverse products of ceramic industries $[1,4]$. The waste composition is source-dependent since pulp and paper mills adopt different chemical recovery processing methods, but is generally composed of calcite $\left(\mathrm{CaCO}_{3}\right)$ as a major crystalline phase $[5,6]$. Due to its calcareous nature, slaker grits have been studied as an alternative raw material of calcium carbonate mostly for building materials [5], collaborating to making the construction industry more sustainable and environmentally friendly. This option can prevent $\mathrm{CaCO}_{3}$ earth extraction, residues landfilling and its consequences, saves energy and water resources, and gives an ecological end to this pulp and paper mill waste [6]. Thus, researches conducted on the economic and environmental issues related to industrial wastes disposal are not only recommended but necessary.

*eduardo.quinteiro@unifesp.br

Dhttps://orcid.org/0000-0002-7233-8815
Oliveira Júnior et al. [7] replaced different percentages of slaker grits on the natural sand aggregate fraction of a mortar to produce an ecological product and reported that 15 wt $\%$ resulted in tensile strength that is $35.1 \%$ higher than the reference mortar and can contribute to compressive, flexural, and tensile strength efficiency. Saeli et al. [8] developed a green geopolymer-based concrete incorporated with slaker grits as aggregate and obtained a product with sufficient mechanical performance for building applications. Siqueira and Holanda [2] produced wall tile formulations bearing up to $15 \mathrm{wt} \%$ of slaker grits waste replacing the formulation calcareous fraction, resulting in optimized densification behavior, physical and mechanical properties, and sintering microstructure. As can be observed, slaker grits waste have been already explored on a wide variety of ceramic products with great outcomes, although, to our best knowledge, this solid residue mainly composed of calcium carbonate has only started to being incorporated on vitreous products as a calcium oxide source. Recently, Silva et al. [9] incorporated this residue on a ternary system $\left(\mathrm{SiO}_{2}-\mathrm{Al}_{2} \mathrm{O}_{3}-\mathrm{CaO}\right)$ as a $\mathrm{CaO}$ source and obtained a glass-ceramic product with properties compatible with the material in group BIa of Brazilian standard for porcelain tiles. The $\mathrm{SiO}_{2}$ source in this study, however, was discarded foundry sand (DFS) and resulted in a dark green glass as a result of the presence of iron oxide in DFS. Thus, the influence of grits alone in glass and glassceramic products with a potential of commercialization has not yet been studied. Among these, ceramic frits are easily produced and have flexible formulations that allow verifying slaker grits incorporation feasibility, especially compositions of high calcium oxide content. On glasses compositions, 
calcium oxide acts as a stabilizer and devitrification agent, increases chemical resistance and hardness, decreases thermal expansion coefficient, acts as a fluxing agent during melting, and leads to crystallization under sintering of the resulting glass [10].

Frits are made by melting a mixture of minerals followed by melt sudden cooling, and each oxide in vitreous formulations collaborate with the structure according to its nature (glass network formers, modifiers, stabilizers, and secondary such as opacifiers and chromophore oxides) $[10$, 11]. One concern about the slaker grits waste application in vitreous products is related to its composition, once inorganic impurities able to interfere on the glass network can be present, such as $\mathrm{SiO}_{2}$ (former), $\mathrm{Na}_{2} \mathrm{O}$ (modifier), $\mathrm{Al}_{2} \mathrm{O}_{3}$ (stabilizer), and $\mathrm{Fe}_{2} \mathrm{O}_{3}$ (chromophore). These oxides content on slaker grits are, respectively, 5.21, 2.77, 0.29, and $1.16 \mathrm{wt} \%$ according to the literature [7]. Considering these inorganic impurities and to maintain formulation stoichiometry, minerals must be carefully weighed. Thus, regarding the need for environmentally friendly methods of disposal and the capacity to solve economic and environmental issues of slaker grits waste, besides its calcareous nature, and the lack of studies related to its incorporation on vitreous products, this study aims to reveal the slaker grits potential to substitute calcium carbonate as a calcium oxide source on a high content calcium ceramic frit composition and verify its influence on the glass properties. To evaluate these eco-friendly frits on their final application on glass-ceramic coating, glazes were obtained and applied on a pre-fired ceramic tile.

\section{MATERIALS AND METHODS}

Frits production and characterization: slaker grits waste, obtained from a Brazilian pulp and paper mill, was incorporated in proportions of $0(\mathrm{~F}-0 \mathrm{G}), 50 \mathrm{wt} \%(\mathrm{~F}-50 \mathrm{G})$, and $100 \mathrm{wt} \%$ (F-100G) on the calcium carbonate content of a commercial ceramic frit formulation (F-C, Table I) as a calcium oxide source. Previous to its addition, the residue was dried at $110^{\circ} \mathrm{C}$ for $48 \mathrm{~h}$ and milled in a hammer miller to obtain particles smaller than $106 \mu \mathrm{m}$ and to guarantee homogeneity. The F-C composition was obtained by X-ray fluorescence spectroscopy (XRF, Zetium, Malvern PANalytical; pressed sample standardless calibration, loss on ignition at $1200{ }^{\circ} \mathrm{C}$ for $2 \mathrm{~h}$ ), and the result was normalized to eliminate oxides with content less than $0.3 \%$. Table II shows the chemical composition of the slaker grits waste, also obtained by XRF with the same conditions. More information about slaker grits can be found in our previous work [6].

The oxide precursors used were sodium bicarbonate $\left(\mathrm{NaHCO}_{3}\right.$, Vetec), magnesium carbonate $\left(\mathrm{MgCO}_{3}\right.$, Synth), aluminum oxide $\left(\mathrm{Al}_{2} \mathrm{O}_{3}\right)$, silicon dioxide $\left(\mathrm{SiO}_{2}\right)$, potassium carbonate $\left(\mathrm{K}_{2} \mathrm{CO}_{3}\right.$, Synth), zinc oxide ( $\mathrm{ZnO}$, Synth), and calcium carbonate $\left(\mathrm{CaCO}_{3}\right.$, Synth) for F-0G and F-50G formulations, and slaker grits waste for F-50G and F-100G. The oxide precursors were carefully weighed to obtain a final product of $100 \mathrm{~g}$ and to maintain the formulation stoichiometry. The mixtures were separately homogenized in a centrifugal miller (CT-241, Servitech) with $\mathrm{Al}_{2} \mathrm{O}_{3}$ milling media of $12 \mathrm{~mm}$ of diameter and a mass ratio of 3:1 (milling media:powder) for $15 \mathrm{~min}$. Each mixture was placed in a fused zirconia-alumina-silica (ZAS) crucible and heated to $900{ }^{\circ} \mathrm{C}$ for $60 \mathrm{~min}$ to promote degasification, and then melted in a pre-heated furnace at $1450{ }^{\circ} \mathrm{C}$ for $30 \mathrm{~min}$ followed by quenching in water at room temperature. No bubbles resulting from gas release from the melt and no crucible corrosion after pouring were observed. The coarse frit from the glasses was collected and dried at $100{ }^{\circ} \mathrm{C}$ for $24 \mathrm{~h}$, and then milled on a centrifugal miller with the previously described conditions for homogenization. The commercial ceramic frit was also milled in the same conditions, and all obtained glass powders had particle sizes smaller than $75 \mu \mathrm{m}$.

The obtained glass powders were analyzed by XRF (Zetium, Malvern PANalytical; pressed sample standardless calibration, loss on ignition at $1200{ }^{\circ} \mathrm{C}$ for $2 \mathrm{~h}$ ) to obtain the final chemical composition. XRF analysis of F-C was remade to prevent errors related to equipment calibration. The milled frits were formed into cylindrical shapes $10 \times 10 \mathrm{~mm}$ and calcined at $900-1200{ }^{\circ} \mathrm{C}\left(5^{\circ} \mathrm{C} / \mathrm{min}, 60 \mathrm{~min}\right)$ to study devitrification behavior. These samples were analyzed by X-ray diffraction (XRD, X'Pert Pro X'Celerator, PANalytical) using CuK $\alpha$ radiation at $40 \mathrm{kV}$ and $30 \mathrm{~mA}$. The patterns were recorded from $10^{\circ}$ to $90^{\circ}(2 \theta)$ range with a scanning step of $0.02^{\circ}$, a duration time of $10 \mathrm{~s}$ for each step, and interpreted using the JCPDS database. Optical dilatometry (Misura, Expert System; $1200{ }^{\circ} \mathrm{C}, 5^{\circ} \mathrm{C} / \mathrm{min}$ ) was performed to evaluate the sintering behavior of cylindrical samples $(3 \times 3 \mathrm{~mm})$. The dimensional changes during heating were registered by a camera and typical thermal characteristics were determined

Table I - Commercial ceramic frit (F-C) formulation (wt \%).

\begin{tabular}{ccccccc}
\hline $\mathrm{Na}_{2} \mathrm{O}$ & $\mathrm{MgO}$ & $\mathrm{Al}_{2} \mathrm{O}_{3}$ & $\mathrm{SiO}_{2}$ & $\mathrm{~K}_{2} \mathrm{O}$ & $\mathrm{CaO}$ & $\mathrm{ZnO}$ \\
\hline 1.94 & 1.55 & 9.27 & 62.89 & 5.53 & 17.44 & 1.38 \\
\hline
\end{tabular}

Table II - Chemical composition (wt\%) of slaker grits waste [6].

\begin{tabular}{lcccccccccccc}
\hline $\mathrm{CaO}$ & $\mathrm{MgO}$ & $\mathrm{SiO}_{2}$ & $\mathrm{Al}_{2} \mathrm{O}_{3}$ & $\mathrm{Fe}_{2} \mathrm{O}_{3}$ & $\mathrm{Na}_{2} \mathrm{O}$ & $\mathrm{K}_{2} \mathrm{O}$ & $\mathrm{P}_{2} \mathrm{O}_{5}$ & $\mathrm{TiO}_{2}$ & $\mathrm{SrO}$ & $\mathrm{MnO}$ & $\mathrm{SO}_{3}$ & $\mathrm{LOI}^{*}$ \\
\hline 55.80 & 0.47 & 1.31 & 0.42 & $<0.10$ & 0.60 & $<0.10$ & 0.65 & $<0.10$ & 0.13 & $<0.10$ & 0.11 & 40.10 \\
\hline
\end{tabular}


according to shape modification (height and contact angle). Sintering temperature $\left(\mathrm{T}_{\mathrm{S}}\right)$ was obtained when sample shrinkage was $5 \%$ of initial height; when samples edges were round, the softening temperature $\left(\mathrm{T}_{\mathrm{M}}\right)$ was given; when in a sphere shape, the ball temperature $\left(\mathrm{T}_{\mathrm{B}}\right)$ was obtained; sample half ball temperature $\left(\mathrm{T}_{\mathrm{HB}}\right)$ was given when sample height was half of the base, and the flow temperature $\left(T_{F}\right)$ when $1 / 3$ of the sample initial height was reached [12]. Frits thermal properties were also studied with a thermal analyzer (STA, 449 F3 Jupiter, Netzsch), allowing to get differential scanning calorimetry (DSC) results. The glass powders were placed in a platin crucible and heated at a constant rate of $20{ }^{\circ} \mathrm{C} / \mathrm{min}$ to $1200{ }^{\circ} \mathrm{C}$ in an argon atmosphere. Total, open, and closed porosity curves were obtained from the fired cylindrical samples $(10 \times 10 \mathrm{~mm})$ at $900-1200{ }^{\circ} \mathrm{C}$ $\left(5{ }^{\circ} \mathrm{C} / \mathrm{min}, 60 \mathrm{~min}\right)$. These calcined frits were subjected to the Archimedes method to obtain water absorption and apparent density, while real densities were determined by helium picnometry (Ultrapyc 1220e, Quantachrome) of crushed calcined samples. The microstructure of the thermally treated samples at $1200{ }^{\circ} \mathrm{C}$ was observed by scanning electron microscopy (SEM, 6400, Jeol) of the freshly fractured surfaces etched with HF for $2 \mathrm{~s}$ and coated with Au (Q150R ES, Quarum). Quartz risk resistance of fired frits was also analyzed (level 7 on the Mohs scale). Colorimetric coordinates on the CIELab system $\left(L^{*}, a^{*}\right.$, and $b^{*}$ parameters) of fired frits were obtained by diffuse reflectance spectrophotometry $\left(2500 \mathrm{D}\right.$, Minolta; D65, $\left.10^{\circ}\right)$, and the color differences $(\Delta \mathrm{E})$ were calculated according to:

$$
\Delta \mathrm{E}=\sqrt{\left(\Delta \mathrm{L}^{*}\right)^{2}+\left(\Delta \mathrm{a}^{*}\right)^{2}+\left(\Delta \mathrm{b}^{*}\right)^{2}}
$$

Glazes production and characterization: glazes were obtained from milled frits and consisted of $65 \%$ of solids (90\% frit and 10\% kaolin) and 35\% of liquid (deionized water; $\%$ in mass), and $1 \%$ of deflocculant agent (Darvan $\mathrm{C}-\mathrm{N}$, Vanderbilt Miner.) in respect to total solid and liquid masses. The mixtures were homogenized in a centrifugal miller with $\mathrm{Al}_{2} \mathrm{O}_{3}$ milling media of $12 \mathrm{~mm}$ of diameter and a 3:1 mass ratio for $5 \mathrm{~min}$. The glaze nomenclatures obtained from the F-C, F-0G, F-50G, and F-100G frits corresponded to E-C, E-0G, E-50G, and E-100G, respectively. The glazes were characterized with respect to their density with a $50 \mathrm{~mL}$ densimeter and to their flow time with a $50 \mathrm{~mL}$ Ford cup of $4 \mathrm{~mm}$ opening. Dilatometric analysis (DIL 402C, Netzsch; Ar atmosphere, $5{ }^{\circ} \mathrm{C} / \mathrm{min}$ ) was performed with dried glaze samples manufactured by slip casting to obtain sintering and linear thermal expansion curves, allowing to determine the thermal expansion coefficient (TEC), glass transition temperature $\left(\mathrm{T}_{\mathrm{g}}\right)$, and dilatometric softening temperature $\left(\mathrm{T}_{\mathrm{d}}\right)$. Glazes were applied on type BIII pre-fired ceramic tile, dried at $100{ }^{\circ} \mathrm{C}$, and finally calcined $\left(1200{ }^{\circ} \mathrm{C}, 5{ }^{\circ} \mathrm{C} / \mathrm{min}\right.$, $60 \mathrm{~min}$ ), obtaining continuous and impermeable layers. These ceramic glazes were later analyzed by colorimetric coordinates in the CIELab system by diffuse reflectance spectrophotometry $\left(2500 \mathrm{D}\right.$, Minolta; D65, $10^{\circ}$ ) and scratch resistance with quartz according to the Mohs scale.

\section{RESULTS AND DISCUSSION}

Frits

Chemical composition: the final chemical compositions of the frits are given in Table III. Compounds with content less than $0.01 \%$ were removed and final results were normalized. Although careful weighing was performed during molten mixture preparation, frit chemical compositions differed on their contents especially for $\mathrm{Na}_{2} \mathrm{O}(1.63-2.82 \mathrm{~mol} \%), \mathrm{MgO}$ (1.33-1.87 mol\%), $\mathrm{Al}_{2} \mathrm{O}_{3}(5.93-8.08 \mathrm{~mol} \%), \mathrm{K}_{2} \mathrm{O}(1.26-3.38$ $\mathrm{mol} \%)$, and $\mathrm{CaO}(20.26-22.02 \mathrm{~mol} \%)$. The origin and purity of the raw materials used to formulate these glasses may have collaborated for this result. $\mathrm{Na}_{2} \mathrm{O}$ and $\mathrm{K}_{2} \mathrm{O}$ are alkaline flux agents that directly affect melt viscosity and also interfere with glass thermal expansion and scratch resistance [13]. Additionally, $\mathrm{K}_{2} \mathrm{O}$ prevents glass crystallization under heating [14] and $\mathrm{K}_{2} \mathrm{O} / \mathrm{Al}_{2} \mathrm{O}_{3}$ ratios below 0.7 are indicative of high viscosity due to replacement of $\mathrm{Ca}^{2+}$ by $\mathrm{K}^{+}$cations at charge compensation sites [15]. Indeed, a high viscosity was observed during frits pouring. The alkaline earth oxide $\mathrm{MgO}$ increases viscosity and decreases thermal expansion, as well as $\mathrm{Al}_{2} \mathrm{O}_{3}$. Finally, $\mathrm{CaO}$ increases viscosity above $1000{ }^{\circ} \mathrm{C}$.

Table III - Chemical compositions (mol\%) of the frits.

\begin{tabular}{ccccc}
\hline Frit & F-C & F-0G & F-50G & F-100G \\
\hline $\mathrm{Na}_{2} \mathrm{O}$ & 1.63 & 2.82 & 2.28 & 2.09 \\
$\mathrm{MgO}$ & 1.87 & 1.45 & 1.43 & 1.33 \\
$\mathrm{Al}_{2} \mathrm{O}_{3}$ & 5.93 & 6.79 & 6.82 & 8.08 \\
$\mathrm{SiO}_{2}$ & 64.85 & 63.72 & 63.95 & 64.12 \\
$\mathrm{P}_{2} \mathrm{O}_{5}$ & 0.01 & 0.04 & 0.04 & 0.04 \\
$\mathrm{SO}_{3}$ & 0.05 & 0.02 & 0.06 & 0.06 \\
$\mathrm{Cl}$ & 0.04 & 0.02 & 0.02 & 0.04 \\
$\mathrm{~K}_{2} \mathrm{O}$ & 3.38 & 1.26 & 1.75 & 1.83 \\
$\mathrm{CaO}$ & 20.26 & 22.02 & 21.75 & 20.65 \\
$\mathrm{TiO}_{2}$ & 0.03 & 0.02 & 0.04 & 0.04 \\
$\mathrm{MnO}$ & 0.02 & nd & 0.03 & 0.01 \\
$\mathrm{Fe}_{2} \mathrm{O}_{3}$ & 0.10 & 0.03 & 0.03 & 0.04 \\
$\mathrm{ZnO}_{20}$ & 1.64 & 1.73 & 1.72 & 1.61 \\
$\mathrm{As}_{2} \mathrm{O}_{3}$ & 0.01 & nd & nd & nd \\
$\mathrm{Rb}_{2} \mathrm{O}$ & 0.03 & nd & nd & nd \\
$\mathrm{SrO}_{\mathrm{ZnO}}$ & 0.09 & 0.06 & 0.07 & 0.06 \\
$\mathrm{ZrO}_{2}$ & 0.06 & 0.01 & 0.03 & 0.03 \\
$\mathrm{CeO}_{2}$ & 0.02 & nd & nd & nd \\
$\mathrm{CaO}_{\mathrm{SiO}}$ & 0.31 & 0.35 & 0.34 & 0.32 \\
$\mathrm{~K}_{2} \mathrm{O} / \mathrm{Al}_{2} \mathrm{O}_{3}$ & 0.57 & 0.19 & 0.26 & 0.23 \\
$\mathrm{SiO}_{2} / \mathrm{Al}_{2} \mathrm{O}_{3}$ & 10.93 & 9.38 & 9.38 & 7.93 \\
$\mathrm{Na}_{2} \mathrm{O}_{2} \mathrm{~K}_{2} \mathrm{O}$ & 5.01 & 4.09 & 4.03 & 3.92 \\
\hline
\end{tabular}

nd: non-detected. 
The effect of these compounds' contents on the glasses' properties is shown in the following results.

Devitrification and sintering behavior: once the first exothermic event due to crystallization was around $900^{\circ} \mathrm{C}$ under DSC study (as shown in the next section), the frits were sintered at temperatures between 900 and $1200{ }^{\circ} \mathrm{C}$, and their respective XRD patterns were recorded to evaluate the crystallization behavior (Fig. 1). From the results, wollastonite- $2 \mathrm{M}\left(\mathrm{CaSiO}_{3}\right.$, $\alpha$-wollastonite, triclinic) crystallized in all calcined frits, typical for silica-based glasses with high calcium contents [16]. It was also observed a discrete halo in the diffractogram baseline on all groups, indicating the presence of a residual vitreous phase typical of glass-ceramic materials [17]. The obtained patterns were in accordance with several published papers $[9,18-$ 20]. Wollastonite glass-ceramic materials have several advantages compared with natural stones, such as low linear thermal expansion coefficient, high strength, low thermal conductivity, low density, and corrosion resistance [20,21]. It is well known that the calcium monosilicate has three modifications: wollastonite (triclinic at room temperature), $\alpha$-wollastonite (monoclinic, also $2 \mathrm{M}$ or parawollastonite), and $\beta$-wollastonite (triclinic, also 4A or pseudowollastonite); these last two forms are produced at elevated temperatures by surface crystallization mechanism [16, 21, 22]; while $\beta$-wollastonite is a lower temperature modification and more
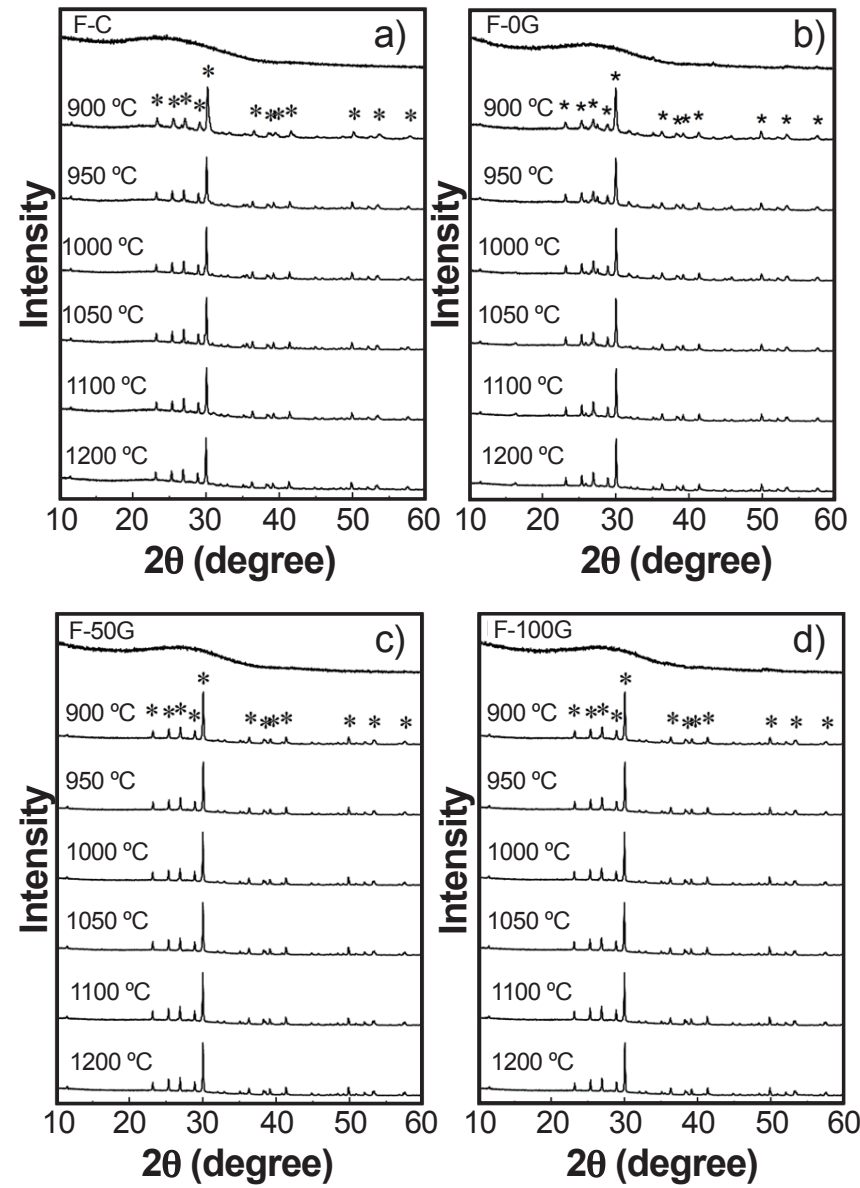

Figure 1: XRD patterns of frits formulations calcined at different temperatures. *: wollastonite-2M ( $\mathrm{CaSiO}_{3}$, JCPDS 01-075-1396). easily obtained, $\alpha$-wollastonite is stable at temperatures above $1100{ }^{\circ} \mathrm{C}$. Different from the expected, $\beta$-wollastonite was not first obtained and transformed into $\alpha$-wollastonite. This effect may be due to the temperature range studied that did not cause this transformation or due to the contaminants present in the glasses (Table III). The same phenomena were observed and described by Silva et al. [9] with slaker grits incorporation in glass and glass-ceramic. In a practical context, wollastonite is commonly used to prevent high shrinkage at elevated temperatures in ceramic products to a degree that is proportional to its addition. Furthermore, and considering the aimed application, the presence of wollastonite polymorphs and their transformations may result in cracks or mismatch in applied ceramic glazes due to their different linear thermal expansion coefficients (TEC). The $\alpha$-wollastonite, for example, has a TEC value of $11.8 \times 10^{-6} \mathrm{~K}^{-1}$ while for $\beta$-wollastonite it corresponds to $6.5 \times 10^{-6} \mathrm{~K}^{-1}[23]$.

Dimensional changes during frit heating by heating microscope analysis and thermal events by DSC are shown in Fig. 2 and characteristic temperatures are summarized in Table IV. The endothermic peaks around $700{ }^{\circ} \mathrm{C}$ indicated the frit vitreous transition temperature $\left(\mathrm{T}_{\mathrm{g}}\right)$. Comparing $\mathrm{F}-\mathrm{C}$ with the synthesized formulations, it can be stated that this characteristic temperature varied only slightly, although the formulation with higher slaker grits content (F-100G) resulted in a $\mathrm{T}_{\mathrm{g}}$ that was $30{ }^{\circ} \mathrm{C}$ higher than $\mathrm{F}-\mathrm{C}$. By comparing the stabilizing agent $\mathrm{Al}_{2} \mathrm{O}_{3}$ content of these glasses, which corresponded to $5.93 \mathrm{~mol} \%$ (F-C) and $8.08 \mathrm{~mol} \%$ (F-100G), the higher amount of alumina in the F-100G glass sample may have collaborated for this uneven $\mathrm{T}_{\mathrm{g}}$ value. The commercial frit $(\mathrm{F}-\mathrm{C})$ presented, in the heat treatment interval, a uniform reduction of sample height starting from around $700{ }^{\circ} \mathrm{C}$, reaching $40 \%$ of its initial height at $1200{ }^{\circ} \mathrm{C}$. The exothermic events identified for F-C were less intense in comparison with all the synthesized frits, although wollastonite crystallization was verified throughout all the temperature range (Fig. 2). The synthesized frit containing high purity calcium carbonate as the only calcium source (F-0G) also revealed a single exothermic event $\left(991{ }^{\circ} \mathrm{C}\right)$ attributed to wollastonite crystallization (Fig. 2), which was the only major devitrified phase. However, F-0G reached at $1200{ }^{\circ} \mathrm{C}$ surprisingly $70 \%$ of its initial height, differing $30 \%$ of the F-C. At $1200{ }^{\circ} \mathrm{C}$ and according to Table IV, while F-0G had already reached the flow temperature $\left(\mathrm{T}_{\mathrm{F}}\right), \mathrm{F}-\mathrm{OG}$ was not even at the ball temperature $\left(\mathrm{T}_{\mathrm{B}}\right)$. This indicated that $\mathrm{F}-0 \mathrm{G}$ was far from having the same mobility as $\mathrm{F}-\mathrm{C}$ at $1200{ }^{\circ} \mathrm{C}$, justifying this difference of shrinkage. Considering the chemical composition, the major differences between F-C and F-0G were the contents of $\mathrm{K}_{2} \mathrm{O}$ (3.38 and $1.26 \mathrm{~mol} \%$, respectively) and $\mathrm{Na}_{2} \mathrm{O}$ (1.63 and $2.82 \mathrm{~mol} \%$, respectively) and, as a fluxing agent, this combination of oxides accelerated the flow on F-C compared to F-OG. Additionally, F-0G had the lowest $\mathrm{K}_{2} \mathrm{O} / \mathrm{Al}_{2} \mathrm{O}_{3}$ ratio, indicating a higher viscosity compared to the other frits [15], thus the densification under sintering became difficult. 


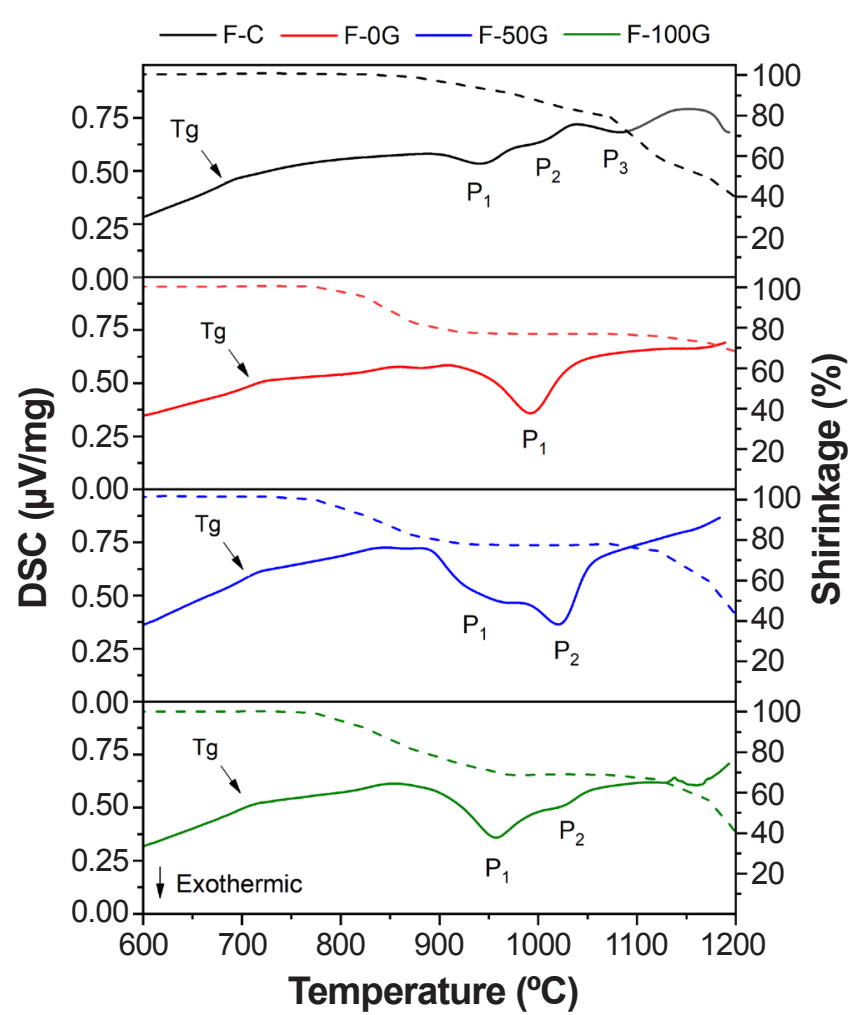

Figure 2: Thermal events by DSC curves (solid lines) and dimensional change curves by heating microscopy (dashed lines) for the frit formulations. $\mathrm{T}_{\mathrm{g}}$ : glass transition temperature; $\mathrm{P}_{1}$ : peak $1 ; \mathrm{P}_{2}$ : peak $2 ; \mathrm{P}_{3}$ : peak 3 (Table IV).

The frits containing partial and total calcium carbonate substitution by grits (F-50G and F-100G, respectively) were very similar in shrinkage to $\mathrm{F}-\mathrm{C}$ and also presented wollastonite as the only major devitrified phase. However, differently from F-C and F-OG, these grits-containing frits presented two exothermic peaks related to crystallization at close temperatures (Fig. 2). The same observation was found by Soares et al. [19] on a study of a silicate-based glass with 20 mol\% CaO. Wiesner and Bansal [24] studied the crystallization behavior of glass in the $\mathrm{CaO}-\mathrm{MgO}-\mathrm{Al}_{2} \mathrm{O}_{3}-\mathrm{SiO}_{2}$ system also containing high calcium content (21.9\% in mass), noticing only wollastonite devitrification by XRD and two crystallization events by DSC. They suggested these two exothermic events occur when there is a significant contribution of the superficial crystallization on the glass particles due to the increase of sites for heterogeneous nucleation [24]. Considering the phenomena described by Wiesner and Bansal [24] on this system, it can be stated that grits-containing frits (F-50G and F-100G) tended to result in greater intensity on the superficial devitrification than F-C and F-0G. This result may be probably due to the nucleation induced by contaminants in very small proportions (non-detected by the chemical analysis equipment) presented on slaker grits, once they can provide heterogeneous nucleation sites on the glass surface, thus facilitating crystallite growth from the glass particles surface towards the center. Glasses on which this phenomenon occurs are usually more suitable for powder processing because, due to their lower crystallization rate, the enhancement of viscous sintering to high density is expected [9, 25]. Additionally, crystallization is highly dependent on the content of the oxide present in glass formulation. F-C, for example, had $3.38 \mathrm{~mol} \%$ of $\mathrm{K}_{2} \mathrm{O}$, an amount that is a lot higher than the synthesized glasses; as an oxide that suppresses crystallization, it is expected a smaller devitrification degree compared to the other glasses.

Fig. 3 shows the porosity changes (total, closed, and open porosities) according to the sintering temperature between 900 and $1200{ }^{\circ} \mathrm{C}$ as a complementary analysis. In the entire temperature range, open porosity was less than $1 \%$ for all frits. A similar sintering behavior in respect to total porosity was observed for F-C, F-50G, and F-100G groups, where the total and closed porosity: i) decreased from 1000 to $1050{ }^{\circ} \mathrm{C}$; ii) increased from 1050 to $1100{ }^{\circ} \mathrm{C}$; and iii) decreased again from 1100 to $1200{ }^{\circ} \mathrm{C}$. These stages correspond to the following phenomena: i) during sintering, a decrease of closed and total porosity was expected due to densification, being the cause of the first event; ii) by increasing temperature, the porosity increased due to low viscosity liquid phase formation and by the pressure inside the pore, causing its expansion [26]; and iii) at even higher temperatures, the glass was already at the flow point and the porosity tended to decrease. Thus, the behavior observed for F-C, F-50G, and F-100G was expected, while $\mathrm{F}-0 \mathrm{G}$ diverged from the other glasses, revealing at $1200{ }^{\circ} \mathrm{C}$ an exaggerated increase in the total porosity. Once F-0G was only at the ball point at $1200{ }^{\circ} \mathrm{C}$, in contrast with F-C, F-50G, and F-100G that were already flowing, it was still at stage ii while the other glasses were at stage iii. The commercial ceramic glazes on a substrate have a porosity behavior during sintering that allows permeation and elimination of gases from substrate compound decomposition at specific temperatures (usually between 600 and $1000{ }^{\circ} \mathrm{C}$ ). Thus, the similar porosity pattern among F-C, F-50G, and F-100G, as shown in Fig. 3, is of great relevance in the viability of ceramic glaze elaboration using the grits residue.

Table IV - Characteristic temperatures of frits.

\begin{tabular}{|c|c|c|c|c|c|c|c|c|c|}
\hline \multirow{2}{*}{$\begin{array}{c}\text { Frit } \\
\text { formulation }\end{array}$} & \multicolumn{5}{|c|}{ Heating microscopy $\left({ }^{\circ} \mathrm{C}\right)$} & \multicolumn{4}{|c|}{$\operatorname{DSC}\left({ }^{\circ} \mathrm{C}\right)$} \\
\hline & $\mathrm{T}_{\mathrm{S}}$ & $\mathrm{T}_{\mathrm{M}}$ & $\mathrm{T}_{\mathrm{B}}$ & $\mathrm{T}_{\mathrm{HB}}$ & $\mathrm{T}_{\mathrm{F}}$ & $\mathrm{T}_{\mathrm{g}}$ & Peak 1 & Peak 2 & Peak 3 \\
\hline $\mathrm{F}-\mathrm{C}$ & 973 & 1073 & 1173 & - & 1200 & 695.4 & 942.3 & 1007.1 & 1084.9 \\
\hline $\mathrm{F}-0 \mathrm{G}$ & 874 & 1023 & - & - & - & 717.6 & 991.3 & - & - \\
\hline F-50G & 823 & 873 & 1172 & 1203 & - & 715.7 & 935.6 & 1020.2 & - \\
\hline F-100G & 822 & 922 & 1172 & 1203 & - & 725.5 & 957.2 & 1026.8 & - \\
\hline
\end{tabular}




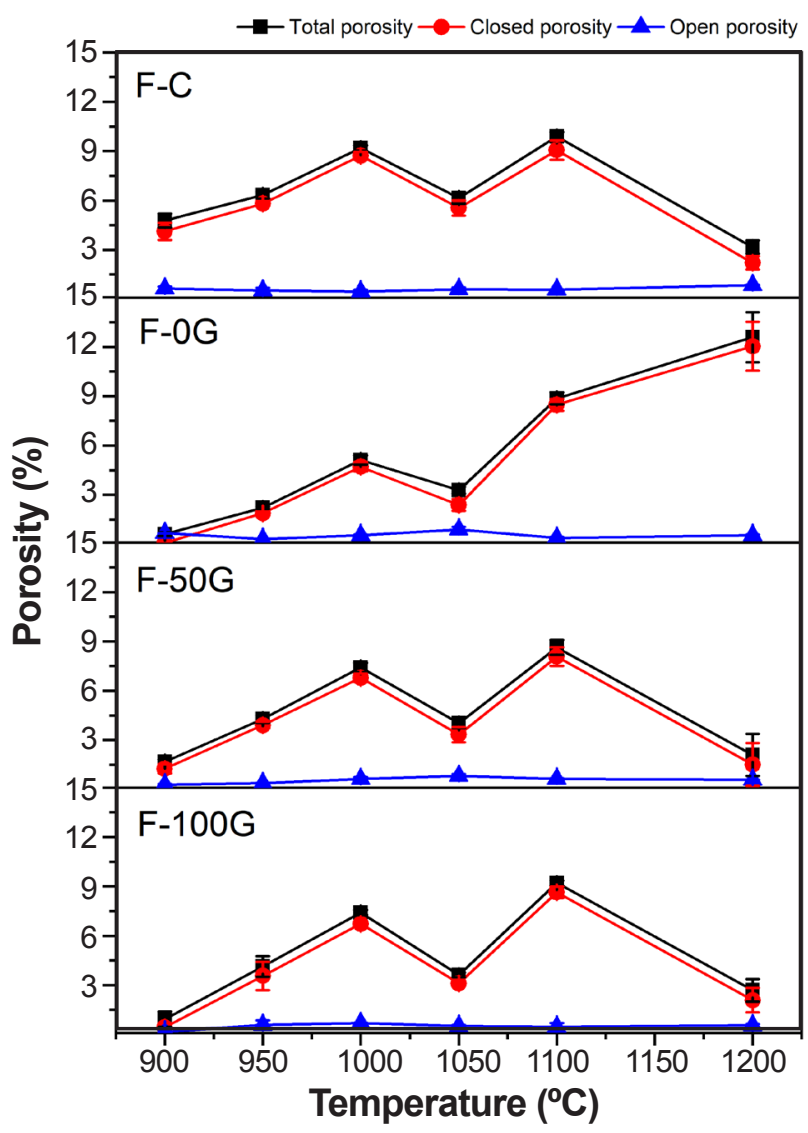

Figure 3: Total, closed, and open porosity of frit formulations calcined at different temperatures.

Morphology: wollastonite-2M crystals on the calcined frits at $1200{ }^{\circ} \mathrm{C}$ can be observed in Fig. 4, where needlelike morphology was found homogeneously on all analyzed surfaces, although in different content. Cracks on the surface were also observed in F-0G and F-100G samples, probably caused during fracturing followed by etching.

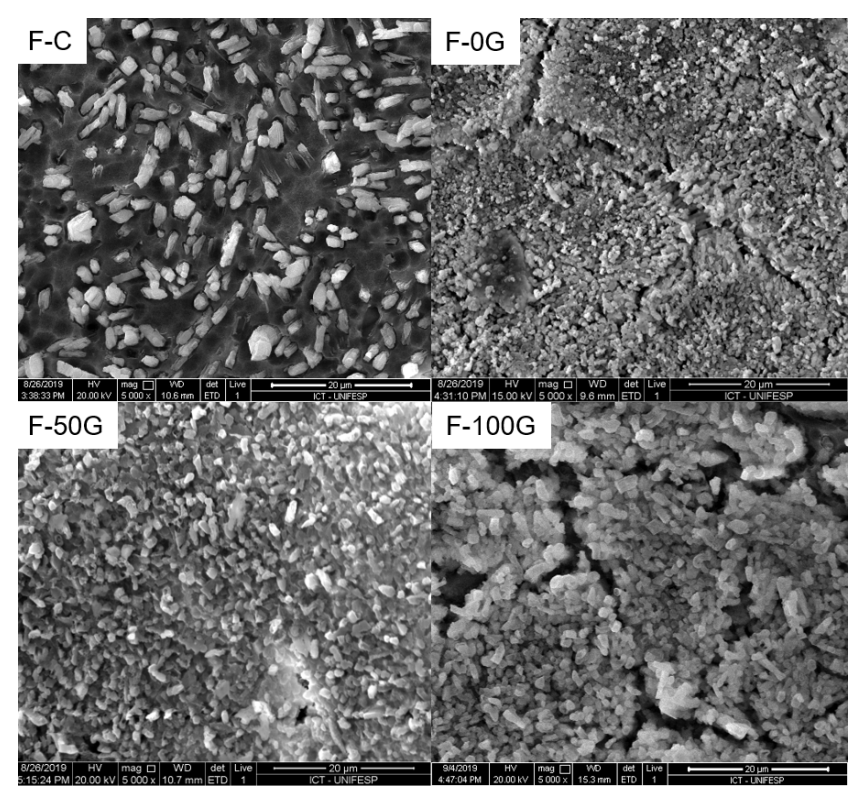

Figure 4: SEM micrographs of thermally treated samples at $1200{ }^{\circ} \mathrm{C}$.
This characteristic morphology of wollastonite-2M was already observed by several authors that studied a calcined high calcium content glass [26-29]. According to SEM micrographs, F-C devitrification was less extent than in the synthesized frits, in which wollastonite-2M crystals within an interlocked residual amorphous phase was observed. This lower devitrification degree in F-C directly affected its glaze properties, as is shown in the next section. Considering F-0G, F-50G, and F-100G, a progressive increase of the wollastonite-2M needle-like crystal size was observed according to grits residue content, at the expense of the amorphous phase. Once again, the heterogeneous nucleation sites on the glass surface generated by slaker grits contaminants may be associated with the $\mathrm{CaSiO}_{3}$ devitrification increase compared with $\mathrm{F}-\mathrm{C}$ and $\mathrm{F}-\mathrm{OG}$, especially the first.

Colorimetric coordinates and scratch resistance: colorimetric coordinates in the CIELab system and the color difference in respect to F-C of the thermally treated frit samples are shown in Fig. 5. It was observed that the $\mathrm{L}^{*}$ parameter became quite similar from $1100{ }^{\circ} \mathrm{C}$ to all groups, reaching values between 94 and 95 . Considering a* parameter, only F-0G revealed a divergent behavior from the commercial frit F-C, presenting a slightly red shade $\left(\mathrm{a}^{*}\right.$

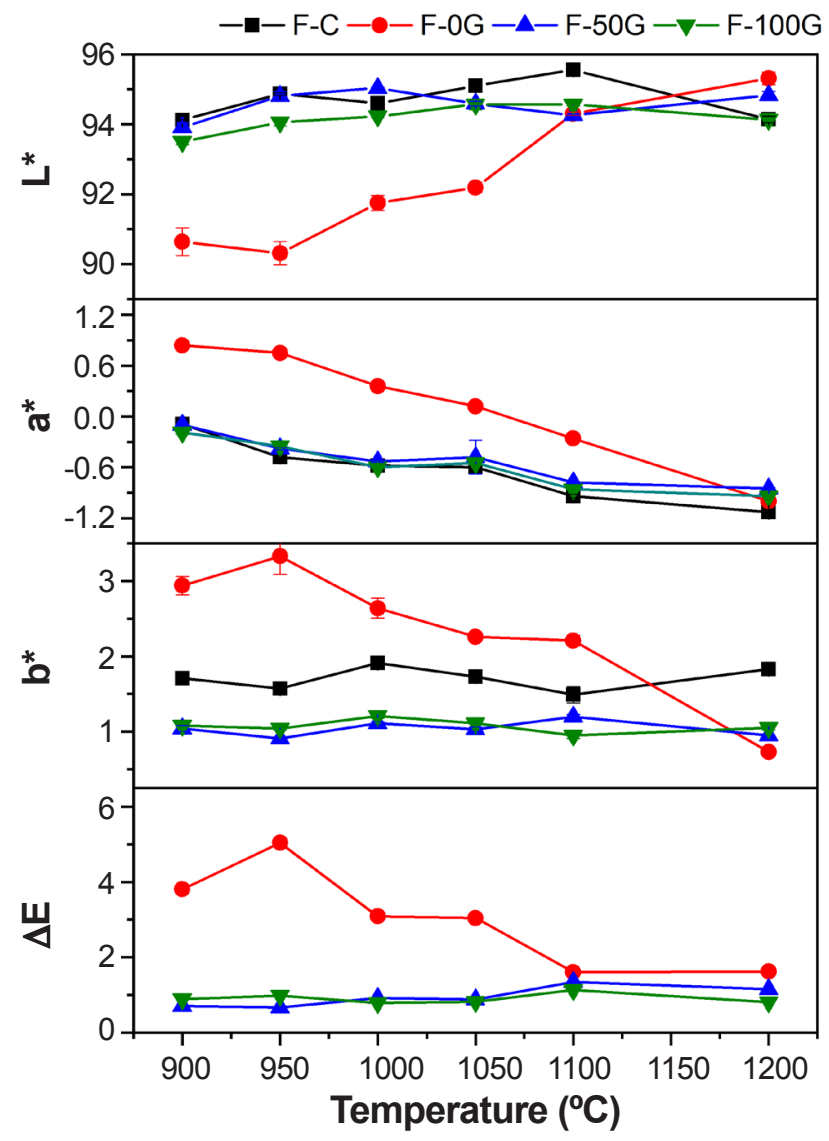

Figure 5: CIELab colorimetric coordinates $\left(\mathrm{L}^{*}, \mathrm{a}^{*}, \mathrm{~b}^{*}\right)$ and color difference in respect to $\mathrm{F}-\mathrm{C}(\Delta \mathrm{E})$ of the frit samples thermally treated at 900 to $1200{ }^{\circ} \mathrm{C}$. 
positive) at earlier temperatures, but that became equal to the other groups at $1200{ }^{\circ} \mathrm{C}$ with a light green shade $\left(\mathrm{a}^{*}\right.$ negative). F-50G and F-100G revealed a lower positive b* parameter than $\mathrm{F}-\mathrm{C}$ on all studied temperatures, indicating a less yellowish shade than F-C and thus, whiter. At the ending temperature, F-0G reached a similar $\mathrm{b}^{*}$ value to the gritscontaining samples while F-C indicated a higher positive $\mathrm{b}^{*}$ value. Considering all the parameters to calculate the color difference $(\Delta \mathrm{E})$, it was observed that grits-containing samples at any content present an equal colorimetric behavior to F-C, and F-0G only at $1200{ }^{\circ} \mathrm{C}$. Thus, it can be stated that grits incorporation into frit formulation resulted in a product with colorimetric coordinates equal to F-C, thus the chromophore oxides presented in their composition $\left(\mathrm{Fe}_{2} \mathrm{O}_{3}, \mathrm{TiO}_{2}\right.$, and $\left.\mathrm{MnO}\right)$ helped to achieve this result since F-0G presented divergent result at earlier temperatures. All sintered samples between 900 and $1200{ }^{\circ} \mathrm{C}$ were quartz scratch-resistant, indicating the hardness was higher than 7 according to the Mohs scale. Considering the natural stones commonly used in the construction industry such as granite and marble and their respective hardness values on Mohs's scale of 5-6 [30] and 3-4.5 [31], all glasses produced presented superior mechanical resistance.

\section{Glazes}

Glass-ceramic materials have properties that outbalance those of natural stones commonly used in the construction industry [14]. Formed after firing, glaze coatings serve to eliminate surface porosity, increase the mechanical strength, and confer aesthetic properties required for ceramic tiles [32]. Considering this final application, glazes from the studied frits were obtained and applied on pre-fired ceramic tile, followed by firing and final product characterization.

Physical properties: the density and flow time of glaze suspensions are summarized in Table V. Little density variation was noted due to the solid content standardization, although glazes containing grits residue presented results more comparable to E-C. Flow time was between 14 and $17 \mathrm{~s}$, indicating the similarity of glazes flow behavior. It is important to comprehend these physical properties once they help to determine further processes in industries, such as milling, homogenization, and glaze application methods.

Table V - Physical properties of glazes.

\begin{tabular}{ccc}
\hline Formulation & Density $\left(\mathrm{g} / \mathrm{cm}^{3}\right)$ & Flow time $(\mathrm{s})$ \\
\hline E-C & 1.744 & $15.9 \pm 0.2$ \\
E-0G & 1.684 & $16.8 \pm 0.2$ \\
E-50G & 1.765 & $14.62 \pm 0.06$ \\
E-100G & 1.778 & $15.09 \pm 0.03$ \\
\hline
\end{tabular}

Thermal properties: glazes sintering curves are given in Fig. 6, and Table VI contains the thermal properties extracted. E-0G, E-50G, and E-100G sintering temperatures were in a narrow range, while $\mathrm{E}-\mathrm{C}$ was $30^{\circ} \mathrm{C}$ higher than the others. In contrast, glazes melting temperatures of gritscontaining samples and E-C were quite similar, while E-0G resulted in higher temperatures. E-C final contraction was around $50 \%$ less than other samples, indicating a specific characteristic of glazes originated from synthesized frits in the laboratory; their very elevated contraction. Once

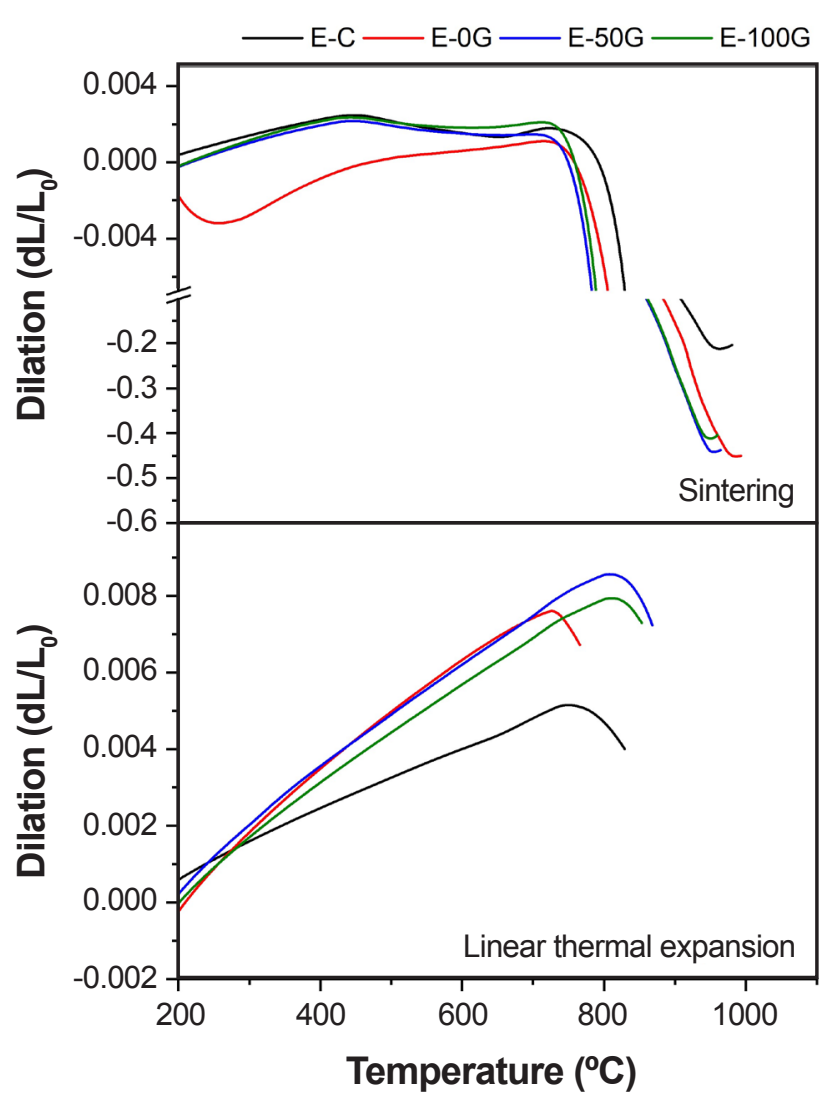

Figure 6: Sintering and linear thermal expansion curves for the glazes formulations.

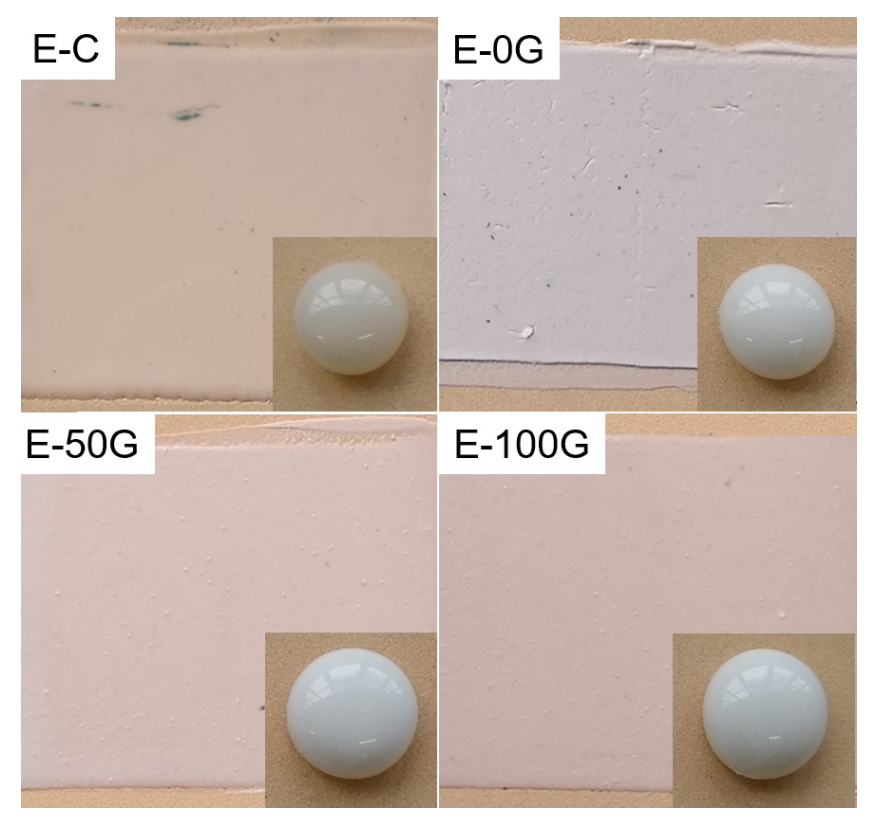

Figure 7: Glazed and sintered ceramic tiles at $1200^{\circ} \mathrm{C}$. 
Table VI - Thermal properties of glazes obtained by dilatometry.

\begin{tabular}{|c|c|c|c|c|}
\hline Property & E-C & E-0G & E-50G & E-100G \\
\hline Sintering temperature ${ }^{\mathrm{a}}\left({ }^{\circ} \mathrm{C}\right)$ & 771.5 & 745.6 & 738.5 & 743.4 \\
\hline Melting temperature $\left({ }^{\circ} \mathrm{C}\right)$ & 962.8 & 986.5 & 954.4 & 949.1 \\
\hline Contraction $^{\mathrm{a}}(\%)$ & 21.2 & 45.1 & 44.2 & 41.2 \\
\hline $\mathrm{TEC}_{250-600^{\circ} \mathrm{C}}{ }^{\mathrm{b}}\left(10^{-5} /{ }^{\circ} \mathrm{C}\right)$ & 0.78 & 1.42 & 1.32 & 1.26 \\
\hline Glass transition temperature ${ }^{\mathrm{b}}\left({ }^{\circ} \mathrm{C}\right)$ & 661.7 & 634.8 & 760.5 & 753.1 \\
\hline Dilatometric softening temperature ${ }^{\mathrm{b}}\left({ }^{\circ} \mathrm{C}\right)$ & 770.5 & 730.8 & 830.4 & 823.7 \\
\hline
\end{tabular}

${ }^{a}:$ obtained from sintering curves; ${ }^{b}:$ obtained from linear thermal expansion curves.
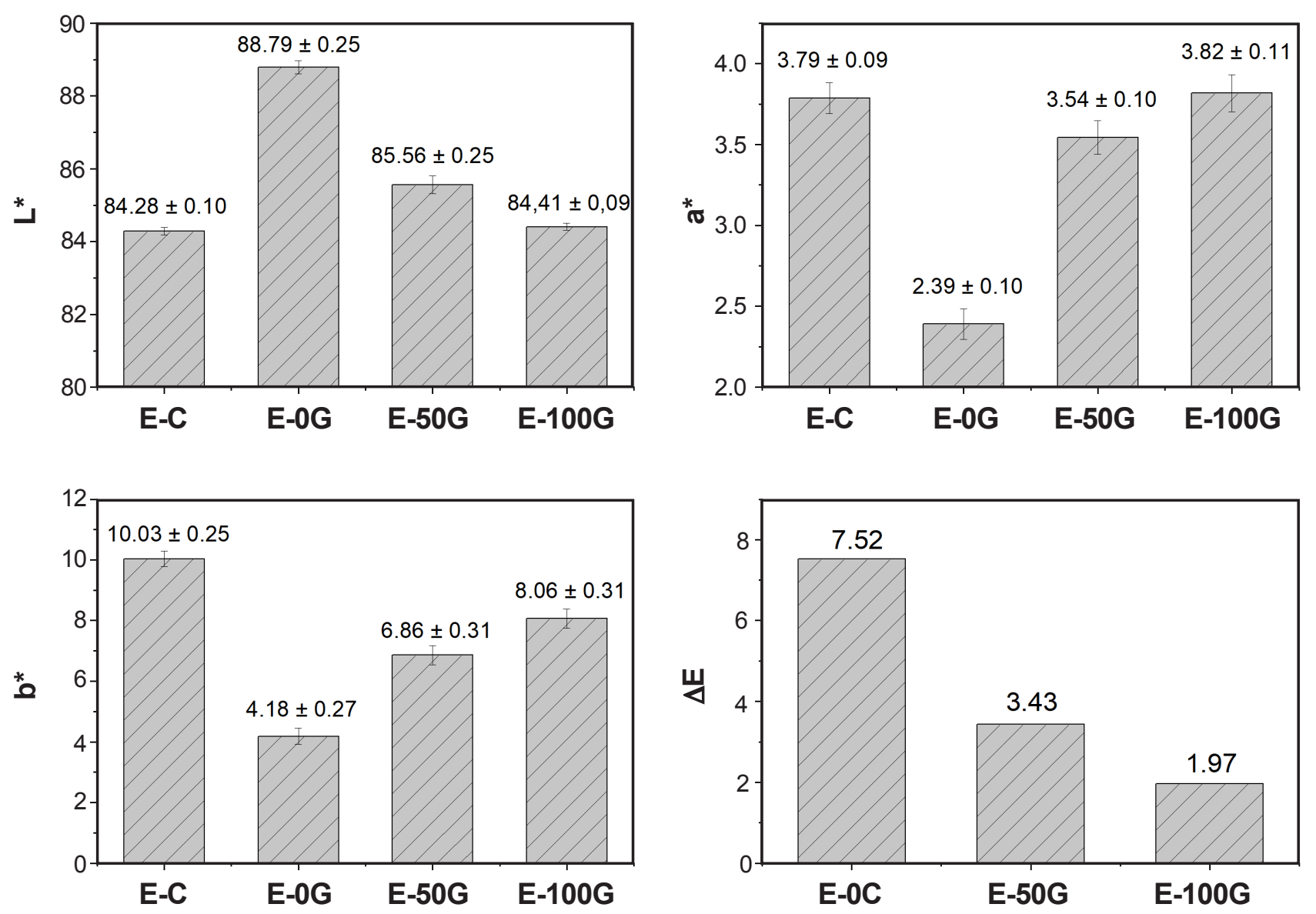

Figure 8: CIELab colorimetric coordinates $\left(\mathrm{L}^{*}, \mathrm{a}^{*}, \mathrm{~b}^{*}\right)$ and color difference in respect to $\mathrm{E}-\mathrm{C}(\Delta \mathrm{E})$ of the glazed ceramic tiles.

this property was similar for grits-containing samples and E-0G, it was noticed that grits residue had little influence on final contraction results, indicating that it acted only as a melting temperature modifier. The obtention of linear thermal expansion curves was performed with previously sintered samples and Table VI summarizes the results. Linear thermal expansion coefficients (TEC) measured from 250 to $600{ }^{\circ} \mathrm{C}$ were considerably lower to E-C compared to other samples, reaching about 50\% difference. Glass transition and dilatometric softening temperatures were highly affected by grits residue in any content, and resulted in approximately 100 and $60{ }^{\circ} \mathrm{C}$ differences on these respective characteristic points. TEC is used to determine coupling or mismatch of the applied glaze and the substrate; considerable differences on this parameter may result in a mismatch, surface cracks, and tile curvatures [21,33]. The linear thermal expansion coefficient is one of the major drawbacks of the double firing method and limits glaze compositions due to the need for similar values [34]. As analyzed, glaze thermal properties varied significantly when compared to the commercial sample E-C. Considering glaze frit sources and their results shown before, the divergence between the thermal behavior of glazes may be attributed to the different wollastonite devitrification levels. Changes in raw material contents in frits containing grits can lead to adjustments on the coefficient of linear thermal expansion 
of the glazes. This reformulation may include alterations in the $\mathrm{SiO}_{2}$ and $\mathrm{Al}_{2} \mathrm{O}_{3}$ ratio (Table III), aiming to achieve F-0G, F-50G, and F-100G values comparable to F-C, that is a $\mathrm{SiO}_{2} / \mathrm{Al}_{2} \mathrm{O}_{3}$ ratio close to 10.93 . This correction would represent an increase in the $\mathrm{SiO}_{2}$ content in frits containing grits, being a great alternative to decrease glaze TEC values [35]. However, an even better and simple alternative would be a small addition of fine-grained quartz in the glaze formulation at the homogenization step during milling. The fine-grained quartz would increase the $\mathrm{SiO}_{2}$ content in the liquid phase that helps to sinter the frits particles, forming part of the crystallized structure and reducing the coefficient of linear thermal expansion. It is important to state that these changes can reflect not only on TEC values but also on the other properties.

Glazed ceramics surfaces: appearance and scratch resistance: samples of glazed and fired ceramic tiles are shown in Fig. 7. Except for E-0G, all samples presented a homogeneous coupled glaze layer. Considering the F-0G frit high melting temperature, E-OG was revealed to be only sintered so that there was no glaze layer completely coupled to the ceramic tile surface, thus resulting in peeling. Acontinuous opacification was observed going from E-C to E-50G and E-100G glazes, resulting in a progressive whiteness in color due to wollastonite devitrification in great content. Thus, except for E-0C, the adhesion was not only mechanical but also chemical. Dried glazes with disc shape were also sintered at $1200{ }^{\circ} \mathrm{C}$ and can also be observed in Fig. 7, where the less devitrification extent on F-C became clear as a result of the great $\mathrm{K}_{2} \mathrm{O}$ content in its respective frit, being less opacified. The colorimetric coordinates of the unpigmented region of glazed ceramic tiles and the color difference with respect to E-C are shown in Fig. 8. The $\mathrm{L}^{*}$ parameter analysis indicated $\mathrm{E}-0 \mathrm{G}$ as the whiter glaze, but this result was not reliable once the layer was only sintered. Considering the grits containing samples and E-C, it can be stated the residue addition resulted in a relatively whiter glaze, probably due to the higher degree of devitrification in wollastonite. A similar reddish color (a* positive) was observed on all samples, except for E-0G, which had lower intensity. Considering the $b^{*}$ parameter, it was easily seen that the greater grits content resulted in a close E-C yellowish color ( $b^{*}$ positive). Thus, the addition of grits residue on the total fraction of $\mathrm{CaCO}_{3}$ as a source of $\mathrm{CaO}$ on the frit formulation $(\mathrm{F}-100 \mathrm{G})$ contained on the glaze (E-100G) led to the lower color difference, as was noted by $\Delta \mathrm{E}$ in Fig. 8. Taking into account E-0G, E-100G, and grits chemical composition, it can be concluded the residue inorganic contaminants helped to achieve colorimetric coordinates close to the commercial glaze E-C. Only E-100G was quartz scratch-resistant, indicating a hardness higher than 7 according to the Mohs scale. It is known that the crystallization process causes an increase in hardness as a natural result [15], and once the wollastonite-2M was more extent for F-100G and consequently E-100G, as indicated by the carried-out characterizations, this result was expected. Thus, by adding grits residue, a glaze with optimized scratch resistance can be achieved.

\section{CONCLUSIONS}

Grits residue was successfully added to the reproduced transparent commercial frit formulation on the total $\mathrm{CaO}$ content, and there were no major differences on this first product analyzed properties considering all samples, except for the wollastonite devitrification degree, which was less for the commercial frit. When frits were used to obtain the glaze, this exception, however, resulted in a wide variance of thermal properties (shrinkage during sintering, linear thermal expansion coefficient - TEC, glass transition temperature, and dilatometric softening temperature). To obtain both frits and glazes containing grits residue with thermal properties comparable to the commercial product, corrections on the frit chemical composition or glaze formulation aiming the prevention of high contraction and elevated TEC must be performed, and further studies must also be considered to evaluate the cause of alterations in the other glass properties. A positive difference between the grits-containing glaze sample and the commercial one was the higher quartz scratch resistance of the first, revealing that the residue can increase this property. Therefore, an environmentally friendly alternative to obtain vitreous ceramic products was studied, and the slaker grits residue potentiality was revealed as a promising alternative raw material for the ceramic coating industrial sector that can prevent calcium carbonate earth extraction and landfilling of wastes, and thus reflecting on a more sustainable process.

\section{ACKNOWLEDGMENTS}

The authors would like to thank CAPES for the financial support of this work and the Federal University of São Paulo for providing the core research facilities - NAPCEM.

\section{REFERENCES}

[1] T. Kinnarinen, M. Golmaei, E. Jernström, A. Häkkinen, J. Clean. Prod. 133 (2016) 953.

[2] F.B. Siqueira, J.N.F. Holanda, Ceram. Int. 44 (2018) 19576.

[3] M. Mäkelä, M.-L. Harju-Oksanen, G. Watkins, A. Ekroos, O. Dahl, Resour. Conserv. Recycl. 67 (2012) 1.

[4] F.B. Siqueira, J.N.F. Holanda, J. Environ. Manage. 131 (2013) 1.

[5] L. Simão, D. Hotza, F. Raupp-Pereira, J.A. Labrincha, O.R.K. Montedo, Cerâmica 64, 371 (2018) 443.

[6] V.R. Santos, M.D. Cabrelon, E.S. Trichês, E. Quinteiro, J. Clean. Prod. 240 (2019) 118220.

[7] A.L. Oliveira Júnior, L.G. Pedroti, J.H.F.A. Oliveira, W. Emílio, A.G. Fineza, S.N. Monteiro, G.H. Nalon, J. Build. Eng. 26 (2019) 100912.

[8] M. Saeli, R.M. Novais, M.P. Seabra, J.A. Labrincha, Mater. Lett. 233 (2018) 94.

[9] L.M.S. e Silva, R.S. Magalhães, W.C. Macedo, G.T.A. Santos, A.E.S. Albas, S.R. Teixeira, Cerâmica 66, 380 (2020) 413. 
[10] J.D. Musgraves, J. Hu, L. Calvez (Eds.), "Springer handbook of glass", Springer, Cham (2019).

[11] A.K. Varshneya, J.C. Mauro, Fundamentals of inorganic glasses, Elsevier (2019).

[12] M. Ahmed, A. Earl, Am. Ceram. Soc. Bull. 81 (2002)

47.

[13] S. Pracidelli, Cerâm. Ind. 13 (2008) 8.

[14] H.R.A. Mooghari, A. Nemati, B. Eftekhari, Z. Hammabard, Ceram. Int. 38, 4 (2012) 3281.

[15] T. Higo, S. Sukenaga, K. Kanehashi, H. Shibata, T. Osugi, N. Saito, K. Nakashima, ISIJ Int. 54, 9 (2014) 2039.

[16] S.R. Teixeira, A.E. Souza, C.L. Carvalho, V.C.S. Reynoso, M. Romero, J.M. Rincón, Mater. Charact. 98 (2014) 209.

[17] E. Ercenk, J. Non-Cryst. Solids 387 (2014) 101.

[18] A.A. Francis, M.K. Abdel Rahman, Cogent Eng. 3 (2016) 1170750.

[19] V.O. Soares, J.K.M.B. Daguano, C.B. Lombello, O.S. Bianchin, L.M.G. Gonçalves, E.D. Zanotto, Ceram. Int. 44 (2018) 20019.

[20] V.F. Pavlov, A.A. Shefer, V.F. Shabanov, Glas. Phys. Chem. 34 (2008) 470.

[21] F. He, J. Xie, D. Han, J. Wuhan Univ. Technol. Mater. Sci. Ed. 23 (2008) 562.

[22] J. Xie, X. Yang, H. Shao, J. Ye, Y. He, J. Fu, C. Gao, Z. Gou, J. Mech. Behav. Biomed. Mater. 54 (2016) 60.

[23] G.M. Azarov, E.V. Maiorova, M.A. Oborina, V.
Belyakov, Glass Ceram. 52, 9 (1995) 237.

[24] V.L. Wiesner, N.P. Bansal, Surf. Coatings Technol. 259 (2014) 608.

[25] T.J. Clark, J.S. Reed, J. Am. Ceram. Soc. 69 (1986) 837. [26] E. Montoya-Quesada, M.A. Villaquirán-Caicedo, R.M. de Gutiérrez, Bol. Soc. Esp. Ceram. V., in press.

[27] M. Magallanes-Perdomo, P. Pena, P.N. De Aza, R.G. Carrodeguas, M.A. Rodríguez, X. Turrillas, S. De Aza, A.H. De Aza, Acta Biomater. 5 (2009) 3057.

[28] S.S. Hossain, S. Yadav, S. Majumdar, S. Krishnamurthy, R. Pyare, P.K. Roy, Ceram. Int. 46 (2020) 833.

[29] S.-D. Yoon, J.-U. Lee, J.-H. Lee, Y.-H. Yun, W.-J. Yoon, J. Mater. Sci. Technol. 29 (2013) 149.

[30] S. Cowie, G. Walton, Eng. Geol. 240 (2018) 204.

[31] D. Eren Sarici, E. Ozdemir, J. Clean. Prod. 201 (2018) 516.

[32] R.C. da Silva, S.A. Pianaro, S.M. Tebcherani, Ceram. Int. 38 (2012) 2725.

[33] G.C. de Souza-Dal Bó, M.D. Bó, A.M. Bernardin, Mater. Chem. Phys. 257 (2021) 123847.

[34] G. Bolelli, V. Cannillo, L. Lusvarghi, T. Manfredini, C. Siligardi, C. Bartuli, A. Loreto, T. Valente, J. Eur. Ceram. Soc. 25 (2005) 1835.

[35] J. Partyka, M. Sitarz, M. Lesniak, K. Gasek, P. Jelen, Spectrochim. Acta A Mol. Biomol. Spectrosc. 134 (2015) 621.

(Rec. 27/01/2021, Rev. 23/04/2021, 11/06/2021, Ac. 18/07/2021) 